\title{
Problems of developing the model for forming parent machine-building enterprise order portfolio under cooperation conditions
}

\author{
Vladimir Volochienko ${ }^{1}$, Ludmila Sorokina $^{2}$ \\ ${ }^{1}$ Professor, Doctor of Economic Sc., Bauman University, Moscow; \\ ${ }^{2}$ Postgraduate Bauman University, Moscow.
}

\begin{abstract}
The article deals with the feature's projects portfolio formation of head enterprise that produces high-tech products. Methods the projects portfolio formation are considered: mathematical, simulation and economicstatistical. The factors that influence the choice of the model are illustrated. It is proposed to carry out research on the basis of creation complexes of interrelated, multi-level models and optimization-simulation approach. The means of implementing this approach are human-machine iterative, interactive procedures. To find the optimal solution by the decision maker, procedures should be based on the identification of the main goals and preferences used in the creation of an optimal of the project portfolio, the study of a set of acceptable parameters and actions.

The head enterprise is considered as a complex system described by several models, to which the control scheme with direct and feedback is applicable, where:

functional breakdown of the process of forming the projects portfolio into separate blocks justifies the use of multi-level modeling of a complex production system;

in long-term planning and forecasting, it is necessary to solve both the direct problem of system consequences for a given "input", and the inverse problem of planning, which has a significant spread of output parameters.

In order to optimize the method, it is proposed to create iterationoptimization analytical models using the two-point boundary value method, including planning from the achieved and planning from the final result. Indicated the advantages of using a specialized mathematical apparatus in the formation of the projects portfolio.

Keywords: organization of production, project portfolio, head enterprise, management scheme, planning purposes, multi-level modeling, iterativeoptimization analytical model, two-point limited value method.
\end{abstract}

\section{Introduction}

The order (project) portfolio formation is an important and difficult task facing each enterprise in the machine-building industry. The complexity of this task is due to the product specifics, high-tech and multi-component production with a long cycle [5]. The enterprise 
effectiveness and sustainability depend on the correct setting of the project portfolio goals and the solution to the problem of its formation [15].

We shall consider the existing approaches to the project portfolio formation for machinebuilding industry enterprises [3], [4], [5], [6], [8], [10], [11] and identify the features of forming the project portfolio of the parent enterprise manufacturing the high-tech production.

\section{Theoretical foundations of forming the order portfolio of the parent enterprise of machine-building industry}

A study of existing approaches and methods of forming the order portfolio shows that there are three main approaches to its modeling: mathematical, simulation and economical and statistical. In accordance with [4], [8], the main basic models can be described in the following ways, presented in the Table 1 .

Table 1.The main basic models

\begin{tabular}{|c|l|}
\hline Model & \multicolumn{1}{|c|}{ Description methods } \\
\hline \multirow{3}{*}{ Optimization } & $\begin{array}{l}\text { Linear programming. } \\
\text { Integer programming. } \\
\text { Boolean programming. } \\
\text { Goal programming. }\end{array}$ \\
\hline \multirow{3}{\text{Simulation}}{} & $\begin{array}{l}\text { Algebraic and logical relations. } \\
\text { Matrix representation (e.g. BCG matrix, McKinsey matrix) } \\
\text { Basic financial ones, based on the forecast of revenue from product } \\
\text { sales. }\end{array}$ \\
\hline $\begin{array}{c}\text { Economical and } \\
\text { statistical }\end{array}$ & $\begin{array}{l}\text { Functional, regression and correlation, probabilistic and statistical, } \\
\text { dynamic description methods }\end{array}$ \\
\hline Empirical & $\begin{array}{l}\text { Logical and intuitive methods (expert, testing, " tree of objectives", } \\
\text { SWOT analysis, BCG) }\end{array}$ \\
\hline Graphic & $\begin{array}{l}\text { Network planning, Pareto diagrams, Gantt charts and other } \\
\text { approaches. }\end{array}$ \\
\hline
\end{tabular}

However, "the variety of planning tasks require not to develop separate models of individual planning functions, but develop systems of models that have both horizontal and vertical relationships and describe the decision-making process as a whole at a particular planning stage. In this case, diverse mathematical apparatus can be used that allows to simulate both linear and non-linear economic dependencies» [4, p. 136]. The creation of complex models and systems of models is required, where one model can be replaced by another depending on the life cycle of the project. Thus, the model choice depends on the enterprise goals.

In most sources, when forming an efficient order portfolio for the machine-building enterprise that manufactures high-tech products, the main goals are:

- economic feasibility (maximum income), while the main criteria are profit maximization [11] and cost minimization [10];

- maintaining the enterprise integrity, which is the main criterion included in the model as "an integrated controlled enterprise parameter that adequately defines specific competence, technological uniqueness, structural, functional and resource configuration, production capabilities and, as a result, the consumer value level of its products" [6, p. 85], that is, "the portfolio of orders must comply with the principle of feasibility at the enterprise", that is, "the order portfolio must comply with the principle of feasibility at this enterprise" [10, p. 108]).

An analysis of the methods used to form order portfolios in various industries showed that most of them are aimed at financial analysis and poorly take into account the production 
potential and order characteristics. The tasks of economic feasibility in most cases are described as the task of multicriteria linear programming and is reduced to the allocation and optimization of objective functions. At that, "most monographs and scientific papers discuss project investments in securities and their derivatives" [12, p. 115]. The traditional approach outlined in the guidelines [7] for promising projects considers only financial and economic indicators (net income, the need for additional financing, etc.), calculated independently for each project. "The considered approach has several disadvantages. In particular, it does not take into account the so-called mandatory (requirements of the law or the regulator) and technologically tightly interconnected projects in the ranking process. The method does not at all take into account deviations in deadlines and finances in previously planned and implemented projects at the enterprise, which must be continued by all means within the limited investment budget" $[12$, p. 118], and only a few companies organize all projects within the framework of a comprehensive project portfolio.

Probabilistic methods (see [6], [3], [14]) and dynamic economic and mathematical models [5] are often used, which also have a number of limitations. For example, in the aircraft industry, the duration of development projects and processes for the manufacturing of high-tech products is about several years and even decades. As a result, a variety of factors can influence the project development and the change in the project portfolio - from the project priority to the achievements of science and technology. Calculations "will have to be carried out on the basis of forecast information with a high degree of uncertainty" [5, p. 345]. "In connection with this, it becomes almost meaningless to use overly detailed, complex particular models that lay claim to high accuracy; in any case, it will not be achieved due to inaccuracy of the initial data" [5, p. 346].

Thus, for an enterprise manufacturing high-tech product, multicriteria tasks and linear programming methods used for them do not always consider all the main project criteria, and probabilistic and dynamic economic and mathematical models, with the high complexity of their implementation, are ineffective over the long term.

\section{Data and methods of forming the order portfolio of the parent enterprise}

Above, attention was drawn to the fact that the main data affecting the choice of the model for forming the project portfolio of any enterprise is the external and internal environmental and enterprise factors. The project portfolio of the parent enterprise that manufactures hightech products also depends on external and internal factors affecting production cooperation, as well as on its parameters [13], [20]. For a more complete presentation of the problem of choosing a model for the formation of the parent enterprise order portfolio, we schematically present only the main external and internal factors (see Fig. 1): 


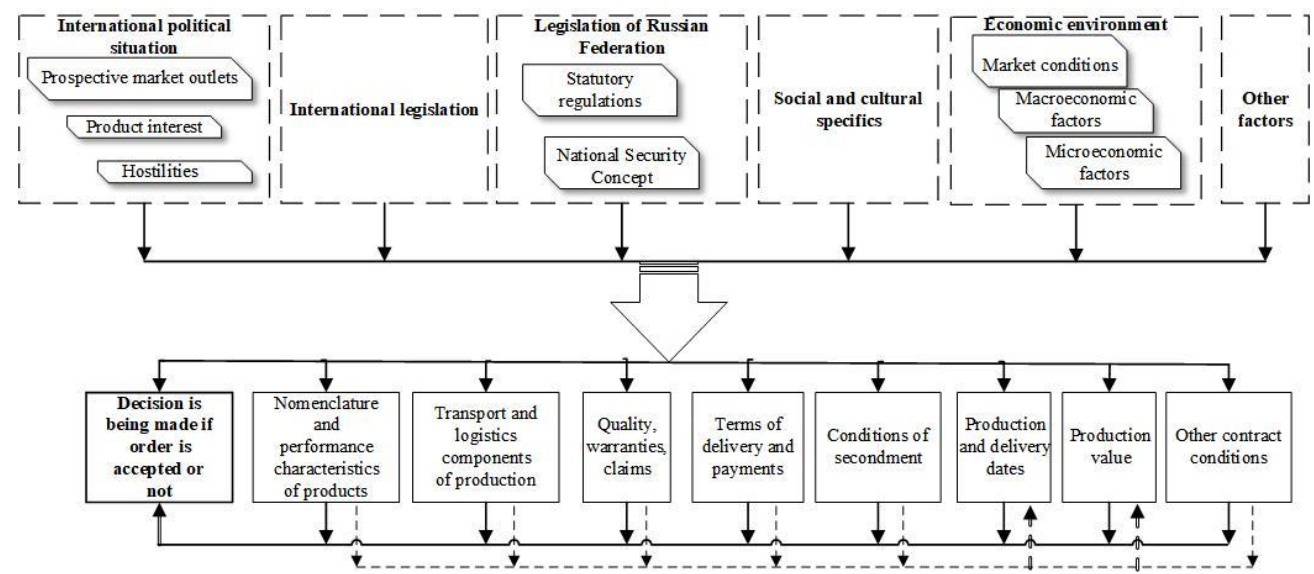

Fig.1. Scheme of the influence of external factors on the characteristics of the project.

It follows from the scheme that the parameters and factors affecting the parent enterprise cover a wide variety of areas of the external and internal environment, from the legislation and regulatory requirements, the coherence and interdependence of projects, to production technologies, managerial tasks and resource constraints. In the models used, it is necessary to take into account economic requirements (profit, payback periods, internal rates of return, liquidity, profitability, etc.).

When forming the project portfolio of the parent enterprise that has wide cooperation, in addition to taking into account the requirements and factors outlined above, it is necessary to solve a number of problems of taking into consideration the specifics of its work with enterprises in the framework of cooperation and various customers. Based on the works of R. Akoff, G. Wagner, F.P. Tarasenko, N.P. Fedorenko, D. Forrester, as well as in a number of other works, it is proposed to consider production cooperation as a developing complex dynamic system, built into a single production and organizational space and considered on the systems approach basis. As noted in the works of S.N. Vasilyev and A.D. Tsvirkun, "When developing large industrial and infrastructure projects, the problem arises of an interconnected description and analysis of various aspects of the activity of the systems: the processes of goal selection and decision making, information processing and production processes. For large industrial and infrastructure projects, it is impossible to describe their properties and features at the same level of detail" [2, p. 15]. Systems are presented in the form of an interconnected set of elements of different levels of detail and stages of development of production" [2, p. 15] and other objects. "The dynamic nature of the tasks of managing the development of large industrial and infrastructure projects requires the creation of formalization and optimization methods - from development scenarios (considering target programs, long-term production development plans, management principles and methods for monitoring the implementation of the plan) to choosing rational production and management structures" [2, p. 15].

In order to smooth out differences in the levels of detail of enterprises in a cooperative production system, some of them can be considered in the form of such an empirical and mathematical model as the "gray box". The "gray box", in contrast to the "black box", allows the parent enterprise to have a part of the necessary information about the enterprise included in the cooperation. The choice of the "gray box" model is due to the fact that, on the one hand, one should not limit oneself to analyzing the system as a "black box", entailing errors, and on the other hand, the ideal state of absolute knowledge about the system and its impeccable description ("white box") when building models and analyzing real systems and processes remains an unattainable ideal. 
As was mentioned, dynamic models give high uncertainty in the long run even for single enterprises of the machine-building industry. And the "precise" models take into account those changes "that have already occurred repeatedly in the past, whereas in the case under consideration it is necessary to evaluate the consequences of future, hypothetical changes in the parameters" [5, p. 346]. In the case of a project portfolio, it is important to consider, to one degree or another, the main significant factors affecting its formation, and not to conduct "precise" modeling of only a few of them. "Thus, when choosing the specification of particular models, preference should be given to simple "soft" models, i.e. structurally stable ones [1]. When changing the parameters, the qualitative nature of the decisions should not change radically, otherwise the validity of the simulation results with high uncertainty of the initial data will be unsatisfactory" [5, p. 346].

As a result of consideration of the features of the formation of the parent enterprise order portfolio as a complex organizational and production system "the parent enterprise together with its cooperation", it is proposed to take into account the composite nature of management in the system, the complexity of its structure, the relationship with other production systems and customers and conduct research on the basis of creating complexes of interconnected, multi-level models and an optimization and simulation approach [16], [19]. Various analytical simulation and optimization models can be used to solve problems of individual enterprises or tasks aimed at achieving various goals of the parent enterprise.

The means for implementing this approach are human-machine iterative, interactive procedures. These procedures should be based on the identification of the main goals and preferences used in developing the optimal order portfolio of the parent enterprise, studying the set of acceptable parameters and actions to find the optimal decision for the person making it [17], [18]. The decision-maker (DM) may be the head of the enterprise or an expert with the appropriate authority.

\section{Iterative approach to creating the analytical simulation and optimization model}

Considering the parent enterprise for the manufacturing of high-tech products as a complex system, described by several models, to which a feedforward and feedback control scheme is applicable, an enlarged scheme of creating the project portfolio of the parent enterprise is presented, shown in Figure 1, and an enlarged scheme of separating the project portfolio formation process into functional blocks (Figure 2). 


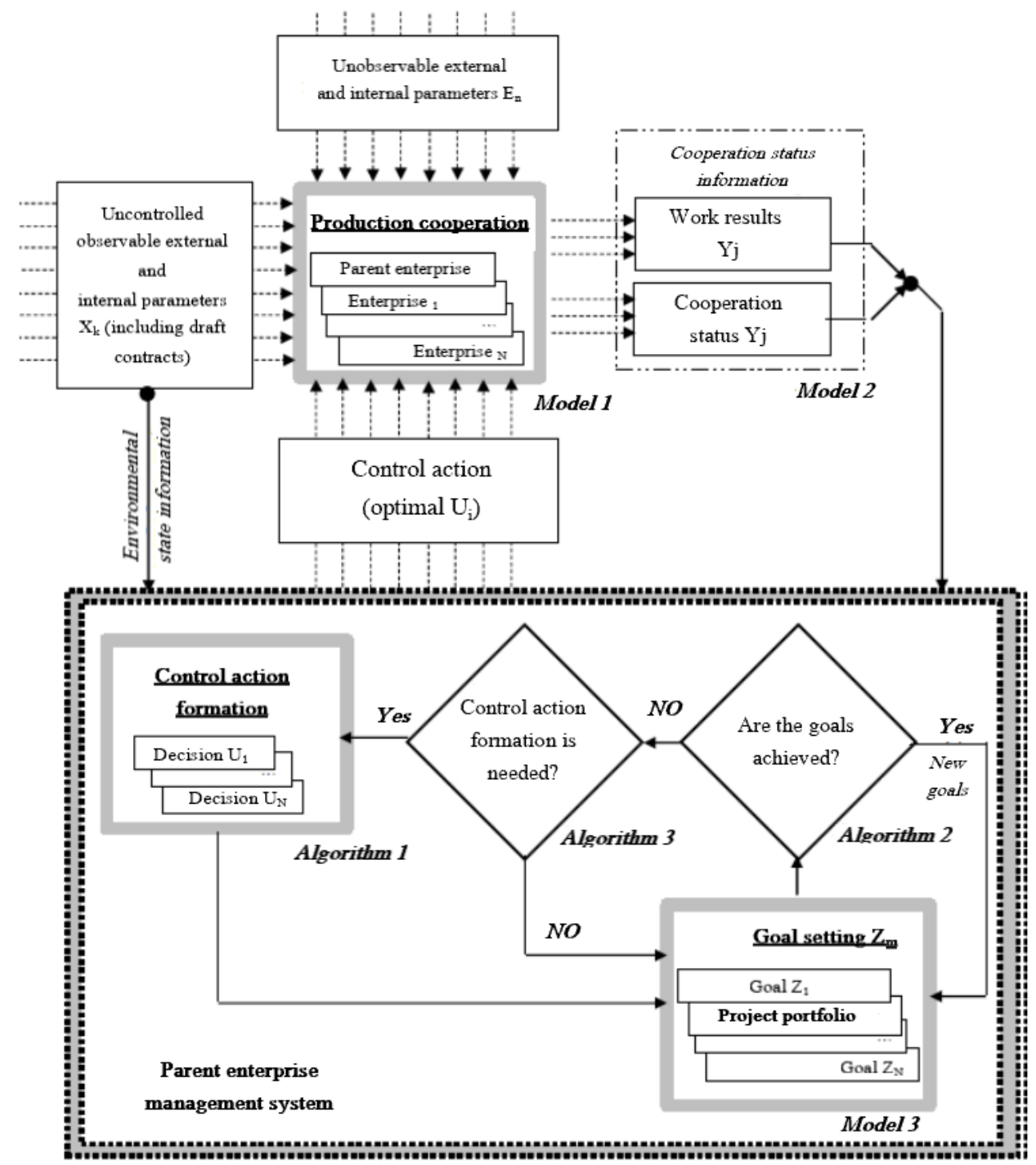

Fig. 2. An enlarged scheme of creating the project portfolio of the parent enterprise. Designed by Authors.

The enlarged scheme for creating the project portfolio of the parent enterprise is constructed using multi-level models and an optimization and simulation approach, namely:

- Model 1 - Organizational and industrial / production model of cooperation.

- Model 2 - The behavioral model of cooperation under given conditions and a given control action.

- Model 3 - Model of goals, including an optimal project portfolio.

- Algorithm 1 - Algorithm for the formation of an optimal control solution and impact on industrial cooperation.

- Algorithm 2 - Algorithm for determination of pursuing the goals.

- Algorithm 3 - Algorithm for determination of the need for the formation of a control action. 


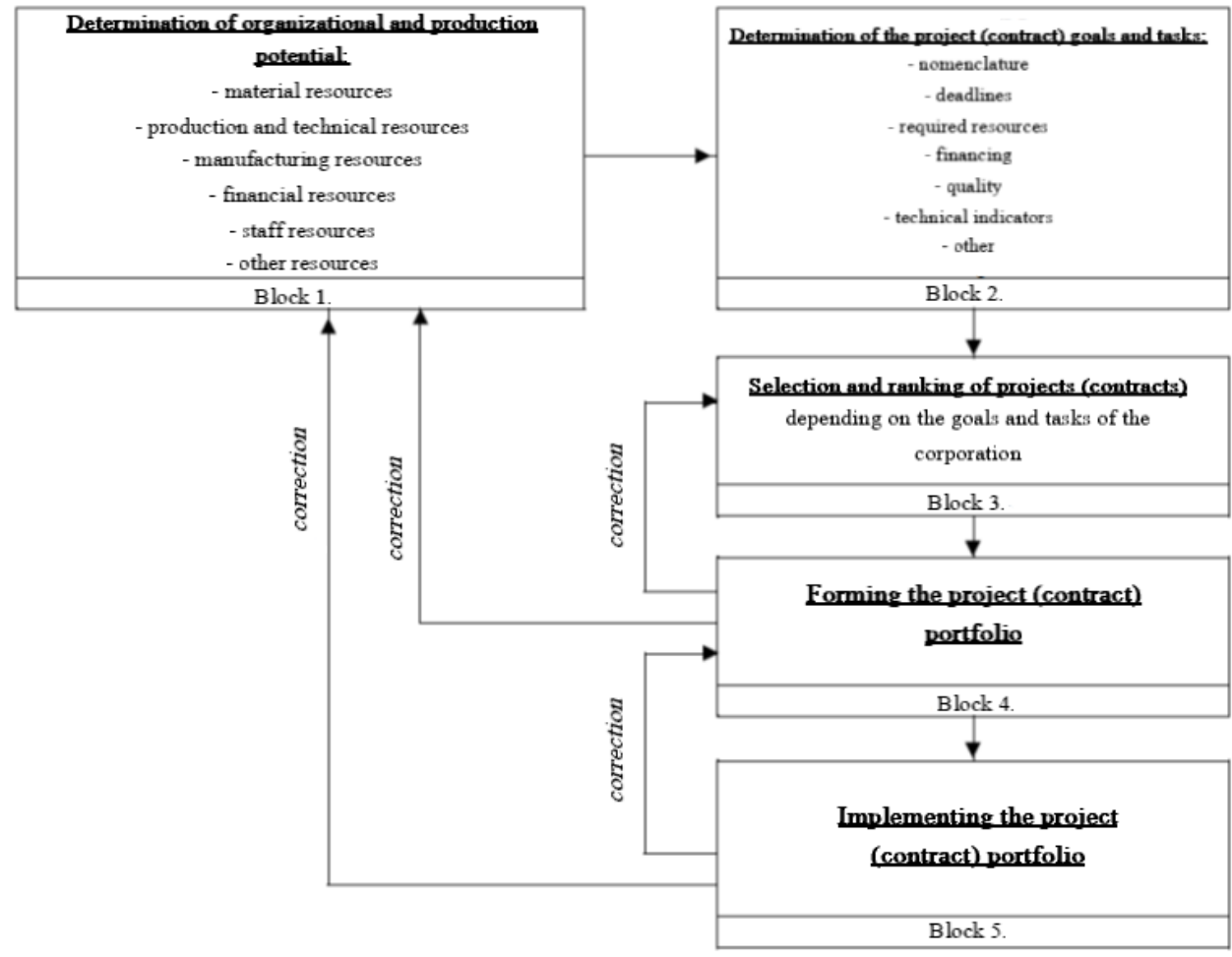

Fig. 3. An enlarged scheme of separating the project portfolio formation process into functional blocks. Designed by Authors.

The functional breakdown of the project portfolio formation process into separate blocks emphasizes the need for multi-level modeling of the complex production system "parent enterprise together with its cooperation".

The key points in the process of managing a complex object are the parameters of entry and exit (goals of forming the project portfolio). Often with long-term planning and forecasting, it is necessary to solve not only the direct problem of system consequences for a given "input", but also the inverse planning task - from the desired result to determining the necessary "input". It should be noted that with the reverse solution, the "input" parameters can have a significant spread and also require an assessment (usually expert one).

In such a situation, it is advisable to use iterative and optimization analytical models and create them using the two-point boundary value method, including planning from the achieved and from the final result, considered in [9]. This will reduce the spread of parameters and ensure the convergence of the simulation.

The method considers two models: the direct (projected future) and the reverse (desired future):

1. The direct model answers the question: "what will be the future of the corporation if the planning policy remains the same as it is now, and other, mainly external, active objects and subjects do not change?" [9, p. 138].

2. The reverse model answers the question: what changes need to be made in the planning policy and in the organization of the production process to achieve the desired result, and not currently predicted one?

As a result of this combined process of creating the model, one can get a forecast of the feasibility of the production program, the results of which can be interpreted by DMs. 
The DM analyzes the simulation results, evaluates their importance and ranks them. The sphere of the most significant tasks is being determined. The greater the difference between the results obtained in the direct and reverse models (for each individual production process), the more critical this production process. The process of planning and organization is being revised, possible corrective actions are being taken to change the production and technological process. Then a new iteration is being performed.

Thus, the convergence of the process and the reach of the optimal result in the formation of the parent enterprise project portfolio are achieved.

The proposed approach will allow the creation of models and calculation methods "with low computational complexity, as well as high performance. If possible, they should be automated for users of various qualifications within the framework of computerized decision support systems" [5, p. 346].

\section{Results}

The paper shows that to achieve the greatest effect in studying and modeling the order portfolio an integrated approach to the selection of goals, criteria and constraints is required. Despite the universality of some methods, it is necessary to configure the analytical and mathematical apparatus for each specific case, taking into account the functioning of the corporation, cooperation enterprises and the specific features of a particular order. It is proposed to use multilevel iterative and optimization analytical models as a method of modeling and choosing the optimal portfolio of the parent enterprise using the two-point boundary value method. This approach will provide easy interpretability of the simulation results by the DM and the convergence of the method.

\section{Conclusion}

The use of a specialized mathematical apparatus as part of integrated information and computing systems of engineering enterprises in the formation and management of the project portfolio of will allow:

- to formalize the functions of the project portfolio formation process and implement multi-level modeling;

- to provide easy interpretability of the simulation result by the DM;

- to ensure the convergence of the results of iterative optimization analytical modeling through the use of the two-point boundary value method;

- to predict at the planning stage the occurrence of critical conditions in the production process, and to provide the DM with the opportunity to take timely, reasonable and competent control action.

The introduction of iterative and optimization analytical modeling in the formation of the project portfolio of the parent machine-building enterprise will significantly increase the efficiency of functioning and development of both the parent enterprise and its cooperation enterprises involved in the creation of high-tech products.

\section{List of abbreviations}

$\mathrm{DM}$ - the decision-maker. 


\section{References}

1. Arnold V I 2004 "Hard" and "soft" mathematical models [«Zhestkiye» i «myagkiye» matematicheskiye modeli] (Moscow: MCCME), $32 \mathrm{p}$.

2. Vasiliev S N and Tsvirkun A D 2016 Problems of managing the development of largescale systems in modern conditions [Problemy upravleniya razvitiyem krupnomasshtabnykh sistem v sovremennykh usloviyakh] Proc. $9^{\text {th }}$ Intl. Conf. Management of Large-Scale System Development (MLSD'2016) Moscow, ICS RAS vol. 1 13-23

3. Gorelik V A and Zolotova T V 2016 Investment portfolio optimization techniques with VAR function as a constraint [Metody optimizatsii investitsionnogo portfelya $\mathrm{s}$ funktsiyey VAR v kachestve ogranicheniya] Proc. $9^{\text {th }}$ Intl. Conf. Management of LargeScale System Development (MLSD'2016) Moscow, ICS RAS vol. 1 125-31.

4. Danilin V I 2006 Operational and financial planning in a corporation (methods and models) [Operatsionnoye i finansovoye planirovaniye $\mathrm{v}$ korporatsii (metody i modeli)] (Moscow: Nauka), 334 p.

5. Klochkov V V 2016 System modeling of technological development of civil aircraft and air transport: methodological foundations and current problems [Sistemnoye modelirovaniye tekhnologicheskogo razvitiya grazhdanskogo aviastroyeniya i vozdushnogo transporta: metodologicheskiye osnovy i aktual'nyye problem] Proc. $9^{\text {th }}$ Intl. Conf. Management of Large-Scale System Development (MLSD'2016) Moscow, ICS RAS vol. $1336-47$

6. Krylatkov P P and Prilutskaya M A 2016 Algorithms for the formation of an optimal order portfolio of a machine-building enterprise [Algoritmy formirovaniya optimal'nogo portfelya zakazov mashinostroitel'nogo predpriyatiya] Organizer of production $185-94$

7. Guidelines for the evaluation of investment projects and their selection for financing (second edition) (Moscow: Ekonomika), 2000, 421 p.

8. Mishin V M 2003 Management systems research: Textbook for high schools [Issledovaniye sistem upravleniya: Uchebnik dlya vuzov] (Moscow: UNITY-DANA), $527 \mathrm{p}$.

9. Saati T 1993 Decision making. Hierarchy analysis method [Prinyatiye resheniy. Metod analiza iyerarkhiy] (Moscow: Radio i svyaz'), 278 p.

10. Sorokina Ye I 2007 Integrated order portfolio management at the enterprise based on cost minimization [Integrated order portfolio management at the enterprise based on $\begin{array}{lllll}\text { cost minimization] Russian Economics online-journal } & \mathbf{1} & 108\end{array}$ https://readera.org/kompleksnoe-upravlenie-portfelem-zakazov-na-promyshlennompredprijatii-na-osnove-142109299.

11. Sorokina Ye I 2007 Formation of an effective order portfolio at enterprises selling hightech products [Formirovaniye effektivnogo portfelya zakazov na predpriyatiyakh, realizuyushchikh naukoyemkuyu produktsiyu] Economic sciences 4 (29) 340-3.

12. Tsisarskiy A D 2015 Project management for the creation of promising rocket and space technology products: Monograph (Moscow: Publishing House "Economic Newspaper" [《Ekonomicheskaya gazeta»]), $150 \mathrm{p}$.

13. Project Management Institute. The Standard for Program Management - Third Edition, 2013, 186 p.

14. Baker R and Kharrat T 2018 Event count distributions from renewal processes: fast computation of probabilities/IMA Journal of Management Mathematics 29 415-33

15. Eriksson $M$ The history and evolution of product management Independent. https://www.mindtheproduct.com/2015/10/history-evolution-product-management/ 
16. Formento H R et al 2013 Key factors for a continuous improvement process Journal of Management \& Production (IJM\&P) vol. 42 391-415 http://www.ijmp.jor.br

17. Jurison J 2017 Communications of AIS. Software Project Management: The Manager's View vol. 2 article $1757 \mathrm{http} / / /$ cais.isworld.org./articles/2-17/

18. Rubenstein D Mar 12007 Standish group report: There's less development chaos today SD Times http://www.sdtimes.com/article/story-2070301-01.html

19. Santos J A N et al 2014 Development of methodology for implementation of strategic planning - MISP Journal of Management \& Production (IJM\&P) vol. $5124-44$ http://www.ijmp.jor.br

20. Sorokina L B 2019 Development of technical and economic characteristics of company project portfolio Science, Engineering and Business: I Interacademic Conference for Graduate Students and Young Researchers (April 16-17 2019) Conference Proceedings and Papers (Moscow: BMSTU Publishing House) 78-85 